\title{
Treatment of Refractory Depression with High-Dose Thyroxine
}

\author{
Michael Bauer, M.D., Ph.D., Rainer Hellweg, M.D., Klaus-Jürgen Gräf, M.D.,
} and Andreas Baumgartner, M.D.

In an open clinical trial we investigated whether addition of supraphysiological doses of thyroxine $\left(T_{4}\right)$ to conventional antidepressant drugs has an antidepressant effect in therapy-resistant depressed patients. Seventeen severely ill, therapy-resistant, euthyroid patients with major depression (12 bipolar, five unipolar) were studied. The patients had been depressed for a mean of $11.5 \pm 13.8$ months, despite treatment with antidepressants and, in most cases, augmentation with lithium, carbamazepine, and neuroleptics. Thyroxine was added to their antidepressant medication, and the doses were increased to a mean of $482 \pm$ $72 \mu \mathrm{g} /$ day. The patients' scores on the Hamilton rating Scale for Depression (HRSD) declined from $26.6 \pm 4.7$ prior to the addition of $T_{4}$ to $11.6 \pm 6.8$ at the end of week 8 . Eight patients fulfilled the criteria for full remission (a 50\% reduction in HRSD score and a final score of $\leqslant 9$ ) within 8 weeks and two others fully remitted within 12 weeks. Seven patients did not remit. The 10 remitted patients were maintained on high-dose $T_{4}$ and followed up for a mean of $27.2 \pm 22.0$ months. Seven of these 10 remitted patients had an excellent outcome, two had milder and shorter episodes during $T_{4}$ augmentation treatment, and one failed to profit from $T_{4}$ treatment during the follow-up period. Side effects were surprisingly mild, and no complications were observed at all. In conclusion, augmentation of conventional antidepressants with high-dose $T_{4}$ proved to have excellent antidepressant effects in approximately $50 \%$ of severely therapy-resistant depressed patients.

[Neuropsychopharmacology 18:444-455, 1998]

(C) 1998 American College of Neuropsychopharmacology. Published by Elsevier Science Inc.
KEY WORDS: High-dose thyroxine; Major depression; Therapy-resistant depression

Major depression is generally viewed as a disorder with a relatively favorable prognosis. Nonetheless, in recent years several epidemiologic studies have unanimously reported that between about 5 and 15\% of depressed patients become chronically ill, i.e., they fail to recover over a period of several years (Lee and Murray 1988; Scott 1988; Keller et al. 1992; Howland 1993; Picinelli

From the Department of Psychiatry (MB, RH) and Nuclear Medicine (AB), Klinikum Benjamin Franklin, Free University of Berlin, Berlin, Germany; and the Department of Medicine (K-JG), Klinikum Rudolf-Virchow, Humboldt University, Berlin, Germany.

Address correspondence to: Dr. A. Baumgartner, Department of Nuclear Medicine (Radiochemistry), Klinikum Benjamin Franklin, Hindenburgdamm 30, D-12200 Berlin, Germany.

Received July 21, 1997; accepted August 21, 1997. and Wilkinson 1994; Thase and Rush 1995; Thase et al. 1995). All of these epidemiologic studies investigated the course of mood disorders in a more or less "naturalistic" design, i.e., the long-term therapy of the depressed patients was not standardized. The question therefore arises as to whether chronically depressed patients might profit from more rigid, standardized therapeutic strategies. Such strategies could include treatment with different classes of antidepressants in sufficiently high doses over not less than 6 weeks respectively, as well as several "augmentation strategies" such as the addition of lithium, triiodothyronine $\left(\mathrm{T}_{3}\right)$ or neuroleptics, and electroconvulsive therapy (Thase and Rush 1995; Thase et al. 1995). With respect to thyroid hormones, several older studies reported that the addition of low-dose (25-50 $\mu \mathrm{g} /$ day) triiodothyronine $\left(\mathrm{T}_{3}\right)$ induced an acceleration of the response to tricyclic anti- 
depressants (e.g., Prange et al. 1969). Later, the addition of $\mathrm{T}_{3}$ to conventional antidepressants was found to be highly effective in treatment-resistant depressed patients in some studies (e.g., Goodwin et al. 1982; Joffe and Singer 1990; Joffe et al. 1993), but not all (e.g., Garbutt et al. 1986; Gitlin et al. 1987; Thase et al. 1989a; for a review, see Joffe et al. 1995). An interesting hypothesis on the mechanism of action of $\mathrm{T}_{3}$ was put forward by Joffe et al. (1984, 1995), namely, that depression is a state of relative $T_{4}$ excess and that $T_{3}$ acts by lowering the serum concentrations and subsequently also the brain concentrations of $\mathrm{T}_{4}$ via inhibition of thyroidstimulating hormone (TSH) secretion.

On the other hand, thyroxine $\left(\mathrm{T}_{4}\right)$ itself has now been reported to be effective in the prophylaxis of previously therapy-resistant, rapid-cycling bipolar disorders (Stancer and Persad 1982; Leibow 1983; Bauer and Whybrow 1986, 1990; Hurowitz and Liebowitz 1993). Our own group recently reported that treatment with supraphysiological doses of $\mathrm{T}_{4}$ stabilized previously completely treatment-resistant, severely ill nonrapid cycling bipolar patients (Baumgartner et al. 1994a). In some of these patients prophylaxis with high-dose $\mathrm{T}_{4}$ was initiated during a depressed episode. We gained the impression that in these patients the depressive episode subsided much faster than previously. These observations prompted us to conduct an open clinical trial in which we investigated the effects of high-dose $T_{4}$ augmentation in depressed patients who had failed to respond to conventional pharmacotherapy.

\section{PATIENTS AND METHODS}

As the administration of high doses of $\mathrm{T}_{4}$ must still be regarded as an experimental therapeutic strategy, we thus intentionally accepted for this study only the most severely ill and treatment-resistant depressed patients who sought treatment at the in-or outpatient facilities of the psychiatric clinic between 1990 and 1995. The patients were not included in the trial unless several other available therapeutic and/or prophylactic treatments had already proved ineffective, either during the present episode or previously, and the idea of high-dose $\mathrm{T}_{4}$ treatment thus presented itself as a kind of "last resort" treatment. The patients included in the study were therefore most likely to be more strongly resistant to treatment and had a more serious course of depressive illness than the patients usually included in "augmentation studies," who have as a rule failed to respond to only one previous trial of one antidepressant (Thase and Rush 1995; Thase et al. 1995).

Formally, all patients were required to meet the DSM-III-R (American Psychiatric Association 1987) criteria for major depression or bipolar disorder, depressed. Consensus diagnoses were made at a confer- ence of two independent raters, using information from a diagnostic interview and from previous psychiatric case notes, which were available in all cases (see below). For inclusion in the study the patient had to be considered therapy resistant, according to the following criteria (standardized criteria for nonremission according to Nierenberg and Amsterdam 1990):

- Nonremission after administration of at least two chemically different antidepressant medications, each administered in standardized doses for a period of at least 6 weeks: tricyclics and tetracyclics $>150 \mathrm{mg} /$ day, selective serotonin reuptake inhibitors (SSRI) $>20 \mathrm{mg} /$ day; MAO-inhibitor tranylcypromine $>30$ $\mathrm{mg} /$ day). Nonremission was defined as a failure to achieve a reduction of at least $50 \%$ on the 21 -item version of the Hamilton Rating Scale for Depression (HRSD) (Hamilton 1960) or a final HRSD score of $\geqslant 15$.

- Nonremission on the basis of an analysis of the case history: 13 of the 17 patients who were finally included had been hospitalized at the psychiatric clinic during previous episodes, most of them several times (see Table 1). Case notes giving detailed information on their response or nonresponse to antidepressant therapies during previous episodes were therefore available. For the remaining four patients, this information was obtained from other medical centers or outpatient facilities. Almost all of the patients had indeed been resistant to several different antidepressant treatments in previous episodes. We decided that in these cases when previous nonremission to one or more antidepressants was already evident from the records, one 6-week trial with a sufficiently high dose of a standard antidepressant would be sufficient to consider the patient to be treatment resistant during the present episode also. Five patients for whom nonremission to both tricyclics and lithium had already been established in previous episodes were thus considered to be treatment resistant after only one 6-week trial with one antidepressant (patients nos. 2, 3, 5, 6, and 10; see Table 1).

The patients were also required to fulfil the following additional criteria:

- no history or concomitant abuse of alcohol or addictive drugs, including benzodiazepines

- no serious somatic illnesses or diseases considered to be a contraindication for high-dose $\mathrm{T}_{4}$ treatment, such as severe cardiac insufficiency, a history of myocardial infarction, cardiac arrhythmias, or a history of thyroid adenoma or hyperthyroidism.

Four patients who were already receiving $\mathrm{T}_{4}$ in physiological doses due to lithium-induced subclinical hypothyroidism and whose laboratory values showed them to be euthyroid, were accepted for the study.

Twenty-one patients fulfilling the above criteria 
were considered for inclusion in the study. Four of them then had to be excluded owing to benzodiazepine and amphetamine abuse $(n=1)$, severe cardiac arrhythmias $(n=1)$ and a recent history of autonomic ad- enoma $(n=2)$. Thus, a total of 17 patients was finally accepted for the study.

The following clinical and laboratory investigations were performed for all patients: routine laboratory

Table 1. Demographic and Clinical Data of 17 Patients with Refractory Depression before Thyroxine Treatment

\begin{tabular}{|c|c|c|c|c|c|c|c|c|}
\hline \multirow[b]{2}{*}{ Pat. No. } & \multirow[b]{2}{*}{$\begin{array}{c}\text { Sex/ } \\
\text { Age(Y) }\end{array}$} & \multirow[b]{2}{*}{ DSM-III-R Diagnosis } & \multirow{2}{*}{$\begin{array}{c}\text { Total } \\
\text { No. of } \\
\text { Episodes }\end{array}$} & \multirow{2}{*}{$\begin{array}{l}\text { Average } \\
\text { No. } \\
\text { Episodes/ } \\
\text { Year }\end{array}$} & \multirow{2}{*}{$\begin{array}{c}\text { Length of } \\
\text { Episode before } \\
\mathrm{T}_{4} \text {-Treatment } \\
\text { (month) }\end{array}$} & \multicolumn{3}{|c|}{$\begin{array}{l}\text { Medication during Episode before } \\
\qquad \mathrm{T}_{4} \text { Treatment }\end{array}$} \\
\hline & & & & & & Name & $\begin{array}{c}\text { Dose } \\
\text { (mg/day) }\end{array}$ & $\begin{array}{c}\text { Duration } \\
\text { (month) }\end{array}$ \\
\hline \multirow[t]{8}{*}{1} & \multirow[t]{8}{*}{$\mathrm{F} / 39$} & \multirow{8}{*}{$\begin{array}{l}\text { Bipolar disorder, depressed, } \\
\text { with psychotic features }\end{array}$} & \multirow[t]{8}{*}{4} & \multirow[t]{8}{*}{1} & \multirow[t]{8}{*}{31} & Amitriptyline & 225 & 3 \\
\hline & & & & & & Maprotiline & 250 & 2 \\
\hline & & & & & & Paroxetine & 20 & 1 \\
\hline & & & & & & Nortriptyline & 200 & 1.5 \\
\hline & & & & & & Perazine $^{a}$ & 600 & $>12$ \\
\hline & & & & & & Clozapine $^{a}$ & 700 & 6 \\
\hline & & & & & & Lithium $^{a}$ & $36 \mathrm{mmol}$ & $>12$ \\
\hline & & & & & & $\mathrm{ECT}$ & $17 \times$ & \\
\hline \multirow[t]{3}{*}{2} & \multirow[t]{3}{*}{$\mathrm{F} / 51$} & \multirow{3}{*}{$\begin{array}{l}\text { Bipolar disorder, depressed, } \\
\text { severe }\end{array}$} & \multirow[t]{3}{*}{20} & \multirow[t]{3}{*}{1.6} & \multirow[t]{3}{*}{4} & Fluoxetine & 100 & 2.5 \\
\hline & & & & & & Carbamazepine $e^{a}$ & 800 & 2.5 \\
\hline & & & & & & Thioridazine $^{a}$ & 300 & 2.5 \\
\hline 3 & $\mathrm{~F} / 44$ & $\begin{array}{l}\text { Bipolar disorder, depressed, } \\
\text { moderate }\end{array}$ & 10 & 2.5 & 3 & Fluoxetine & 80 & 1.5 \\
\hline 4 & $\mathrm{~F} / 55$ & Major depression, recurrent, & 1 & - & 50 & Doxepine $^{b}$ & 75 & 10 \\
\hline & & severe & & & & Clomipramine & 250 & 1.5 \\
\hline & & Panic disorder, without & & & & Dibenzepine & 1200 & 4 \\
\hline & & agoraphobia & & & & Nortriptyline & 300 & 1 \\
\hline & & & & & & Fluoxetine & 80 & 1 \\
\hline & & & & & & Clozapine & 250 & 4 \\
\hline & & & & & & Fluspirilene & $0.3 \mathrm{IM}$ & 4 \\
\hline & & & & & & Thioridazine & 50 & 10 \\
\hline & & & & & & Carbamazepine $^{a}$ & 1500 & 2.5 \\
\hline & & & & & & Lithium $^{a}$ & $24 \mathrm{mmol}$ & 0.5 \\
\hline 5 & $\mathrm{~F} / 57$ & Bipolar disorder, depressed, & 30 & 1.2 & 2 & Amitriptyline & 225 & 2 \\
\hline & & with psychotic features & & & & Lithium $^{a}$ & $18 \mathrm{mmol}$ & 2 \\
\hline 6 & $\mathrm{~F} / 42$ & Bipolar disorder, depressed & 10 & 1.9 & 2 & Tranylcypromine & 30 & 2 \\
\hline & & & & & & Lithium $^{a}$ & $30 \mathrm{mmol}$ & 2 \\
\hline & & & & & & Carbamazepine $^{a}$ & 600 & 2 \\
\hline & & & & & & Thyroxine $^{a}$ & 150 & 2 \\
\hline & & & & & & Perazine $^{a}$ & 100 & 2 \\
\hline 7 & $\mathrm{M} / 41$ & Bipolar disorder, depressed, & 3 & 1.5 & 5 & Doxepine & 150 & 1.5 \\
\hline & & severe & & & & Amitriptyline & 150 & 2 \\
\hline & & & & & & Imipramine & 500 & 2 \\
\hline & & & & & & Lithium $^{a}$ & $36 \mathrm{mmol}$ & 2 \\
\hline 8 & $\mathrm{~F} / 46$ & Major depression, recurrent, & 2 & 0.5 & 12 & Doxepine $^{b}$ & 300 & 10 \\
\hline & & severe & & & & Nortriptyline & 200 & 2 \\
\hline & & & & & & Carbamazepine $^{a}$ & 600 & $>12$ \\
\hline & & & & & & Lithium $^{a}$ & $24 \mathrm{mmol}$ & 6 \\
\hline & & & & & & Perazin $^{a}$ & 300 & 6 \\
\hline & & & & & & Thyroxine $^{a}$ & 200 & $>12$ \\
\hline 9 & $\mathrm{~F} / 59$ & Bipolar disorder, depressed, & 10 & 0.4 & 13 & Trimipramine $e^{b}$ & 175 & 6 \\
\hline & & with psychotic features & & & & Trazodone & 250 & 1 \\
\hline & & & & & & Fluoxetine & 100 & 4 \\
\hline & & & & & & Imipramine & 200 & 1.5 \\
\hline & & & & & & Thioridazine $^{a}$ & 600 & 8 \\
\hline & & & & & & Carbamazepine $^{a}$ & 1000 & $>12$ \\
\hline & & & & & & ECT & 17 & \\
\hline 10 & $\mathrm{~F} / 43$ & Bipolar disorder, depressed, & 30 & 1.2 & 2.5 & Doxepine & 225 & 2.5 \\
\hline & & with psychotic features & & & & Lithium $^{a}$ & $24 \mathrm{mmol}$ & 2.5 \\
\hline & & & & & & Perazine $^{a}$ & 400 & 2.5 \\
\hline
\end{tabular}


screening, including red cell count (RBC) and white cell count (WBC), aspartate aminotransferase (GOT), alanine aminotransferase (GPT), creatinine and erythrocyte sedimentation rate (ESR), as well as serum concentrations of TSH and thyroid hormones $\left(\mathrm{T}_{4}, \mathrm{~T}_{3}, \mathrm{fT}_{4}\right)$. In addition a thoracic X-ray, a 24-h echocardiogram (ECG) recording, blood pressure measurement three times a day, and a thorough physical examination by an experienced endocrinologist (K.-J. G.) were performed. Patients with a history of or suspected thyroid disorder also underwent thyroid sonography and scintigraphy.

Detailed demographic data, diagnoses, and information on the previous clinical courses of all 17 patients are provided in Table 1 . Sixteen of the patients were female and one male, and the mean age of the whole group was $50.1 \pm 8.1$ years (range: $39-70$ years). Thir- teen of the patients were receiving treatment as inpatients and four as outpatients. Five patients had unipolar depression and 12 bipolar disorder. Four patients had psychotic features and one an additional diagnosis of panic disorder (patient no. 4, Table 1).

After complete description of the study to the subjects, written informed consent was obtained. The trial protocol had been approved by the Ethics Committee of the Klinikum Rudolf-Virchow of the Free University of Berlin.

\section{Study Design}

All patients included in the study were given $\mathrm{T}_{4}$ in addition to the antidepressive medication they had been receiving during the preceding weeks. The $\mathrm{T}_{4}$ was administered in a single dose each morning. The starting

Table 1. (continued)

\begin{tabular}{|c|c|c|c|c|c|c|c|c|}
\hline \multirow[b]{2}{*}{ Pat. No. } & \multirow[b]{2}{*}{$\begin{array}{c}\text { Sex/ } \\
\operatorname{Age}(Y)\end{array}$} & \multirow[b]{2}{*}{ DSM-III-R Diagnosis } & \multirow{2}{*}{$\begin{array}{c}\text { Total } \\
\text { No. of } \\
\text { Episodes }\end{array}$} & \multirow{2}{*}{$\begin{array}{l}\text { Average } \\
\text { No. } \\
\text { Episodes/ } \\
\text { Year }\end{array}$} & \multirow{2}{*}{$\begin{array}{c}\text { Length of } \\
\text { Episode before } \\
\mathrm{T}_{4} \text {-Treatment } \\
\text { (month) }\end{array}$} & \multicolumn{3}{|c|}{$\begin{array}{l}\text { Medication during Episode before } \\
\qquad \mathrm{T}_{4} \text { Treatment }\end{array}$} \\
\hline & & & & & & Name & $\begin{array}{c}\text { Dose } \\
\text { (mg/day) }\end{array}$ & $\begin{array}{c}\text { Duration } \\
\text { (month) }\end{array}$ \\
\hline \multirow[t]{6}{*}{11} & \multirow[t]{6}{*}{$\mathrm{F} / 46$} & \multirow{6}{*}{$\begin{array}{l}\text { Major depression, recurrent, } \\
\text { with psychotic features }\end{array}$} & \multirow[t]{6}{*}{15} & \multirow[t]{6}{*}{0.9} & \multirow[t]{6}{*}{7} & Imipramine & 300 & 6 \\
\hline & & & & & & Nortriptyline & 200 & 1.5 \\
\hline & & & & & & Lithium $^{a}$ & $30 \mathrm{mmol}$ & 6 \\
\hline & & & & & & Carbamazepine $^{a}$ & 900 & 6 \\
\hline & & & & & & Haloperiodol $^{a}$ & 13 & 2 \\
\hline & & & & & & Perazine $^{a}$ & 450 & 2 \\
\hline \multirow[t]{4}{*}{12} & \multirow[t]{4}{*}{$\mathrm{F} / 53$} & \multirow[t]{4}{*}{ Bipolar disorder, depressed } & \multirow[t]{4}{*}{3} & \multirow[t]{4}{*}{0.5} & \multirow[t]{4}{*}{34} & Maprotiline $^{b}$ & 150 & $>12$ \\
\hline & & & & & & Clomipramine & 225 & 2 \\
\hline & & & & & & Lithium $^{a}$ & $18 \mathrm{mmol}$ & 2 \\
\hline & & & & & & Perazine $^{a}$ & 500 & $>12$ \\
\hline \multirow[t]{4}{*}{13} & \multirow[t]{4}{*}{$\mathrm{F} / 46$} & \multirow{4}{*}{$\begin{array}{l}\text { Bipolar disorder, depressed, } \\
\text { severe }\end{array}$} & \multirow[t]{4}{*}{12} & \multirow[t]{4}{*}{1.9} & \multirow[t]{4}{*}{3} & Amitriptyline & 300 & 1.5 \\
\hline & & & & & & Imipramine & 300 & 1.5 \\
\hline & & & & & & Carbamazepine $^{a}$ & 600 & 3 \\
\hline & & & & & & Thyroxine & $150 \mu \mathrm{g}$ & \\
\hline \multirow[t]{5}{*}{14} & $\mathrm{~F} / 70$ & Bipolar disorder, depressed, & $\sim 70$ & $\sim 1.9$ & 5 & Amitriptyline & 200 & 1.5 \\
\hline & & severe & & & & Fluoxetine & 80 & 2 \\
\hline & & & & & & Paroxetine & 60 & 1.5 \\
\hline & & & & & & Perazine $^{a}$ & 100 & 5 \\
\hline & & & & & & Thyroxine & $100 \mu \mathrm{g}$ & \\
\hline 15 & $\mathrm{~F} / 48$ & Major depression, recurrent, & 13 & 0.7 & 5 & Lofepramine & 280 & 1.5 \\
\hline & & severe & & & & Fluoxetine & 80 & 1.5 \\
\hline & & & & & & Imipramine $^{b}$ & 400 & 2 \\
\hline & & & & & & Lithium $^{a}$ & $24 \mathrm{mmol}$ & 5 \\
\hline & & & & & & Carbamazepine $^{a}$ & 900 & 5 \\
\hline & & & & & & Clozapine $^{a}$ & 300 & 5 \\
\hline 16 & $\mathrm{~F} / 63$ & Bipolar disorder, depressed, & $\sim 30$ & 1.9 & 13 & Amitriptyline & 200 & 2 \\
\hline & & severe & & & & Doxepine & 300 & 3 \\
\hline & & & & & & Clomipramine & 150 & 2 \\
\hline & & & & & & Moclobemid & & 3 \\
\hline & & & & & & Paroxetine & 80 & 3 \\
\hline & & & & & & Carbamazepine $^{a}$ & 900 & 13 \\
\hline & & & & & & Flupentixol $^{a}$ & 3 & 4 \\
\hline 17 & $\mathrm{~F} / 49$ & Major depression, recurrent, & 8 & 0.5 & 4 & Fluoxetine & 60 & 2 \\
\hline & & severe & & & & Lofepramine & 350 & 2 \\
\hline & & & & & & Carbamazepine $^{a}$ & 450 & 4 \\
\hline$\Sigma \pm S D$ & & & $15.9 \pm 17.0$ & $1.1 \pm 0.6$ & $11.5 \pm 13.8$ & & & \\
\hline
\end{tabular}

${ }^{a}$ Lithium, carbamazepine, thyroxine and neuroleptics were given concomitantly with an antidepressant medication.

${ }^{b}$ These treatments were performed outside the facilities of the Psychiatric Department of the Free University. 
dose was $50 \mu \mathrm{g} \mathrm{T}_{4} /$ day, and the dosage was increased by $50 \mu \mathrm{g} /$ day every 3 days, i.e., $100 \mu \mathrm{g} /$ day on day 4 , $150 \mu \mathrm{g}$ on day 7 , etc. until a dose of $500 \mu \mathrm{g} /$ day was reached, usually on day 35 . This dosage was then maintained until day 56 , i.e., the end of the 8 -week treatment period.

Whether this regime was adhered to as prescribed depended on the following criteria:

- Clinical improvement: when improvement had been clinically evident over a 3-day period, no further increases in the dose of $\mathrm{T}_{4}$ were made.

- Side effects: when side effects that were most likely attributable to the $\mathrm{T}_{4}$ medication occurred, the dose was not further increased. Side effects considered to be relevant were tachycardia of over 100 BPM, dyspnea on exercise or restlessness, but not slight tremor or sweating.

- Serum levels of TSH and thyroid hormones: blood samples were drawn for serum every third day, i.e., on the day before the dose of $\mathrm{T}_{4}$ was raised. The results of the hormone determinations were usually available within 3 days and could thus be taken into account when considering the next-but-one increase in the $\mathrm{T}_{4}$ dosage. We raised the dosage of $\mathrm{T}_{4}$ until the TSH concentrations were completely suppressed and the serum level of $\mathrm{T}_{4}$ of each respective patient was approximately double the value determined before institution of $\mathrm{T}_{4}$ treatment.

Throughout the 8-week study, heart rate and blood pressure were monitored daily and an ECG was performed twice weekly. For patients receiving lithium and/or carbamazepine the serum levels of these drugs were determined weekly to ensure that the serum concentrations were within the range considered to be effective ( $\geqslant 0.6 \mathrm{nmol} / \mathrm{L}$ for lithium and $\geqslant 5 \mathrm{mg} / \mathrm{L}$ for carbamazepine).

Ratings on the 21-item Hamilton Rating Scale for Depression (HRSD) were performed on the day before institution of $\mathrm{T}_{4}$ treatment and thereafter every second week, until the end of week 8, always by the same rater (M.B.).

At the end of the 8-week trial the efficacy of highdose $\mathrm{T}_{4}$ augmentation was defined as follows.

- nonremission was defined as a failure to attain a reduction of at least $50 \%$ on the HRSD and the consensus between physician and patient that a change in treatment plan (e.g., a trial of electroconvulsive therapy) was necessary;

- partial remission was defined as a reduction of $\geqslant 50 \%$ in the HRSD score, but a final score of $\geqslant 10$;

- response was defined as a reduction of $\geqslant 50 \%$ in the HRSD score and a final score of $\leqslant 9$, resulting in an almost symptom-free condition requiring no further changes in therapy.

At the end of week 8 the patient, the treating physi- cian, and the investigator met to discuss whether in the respective case $T_{4}$ medication should be maintained or withdrawn.

The clinical courses of each of the patients who continued to receive high-dose $T_{4}$ were regularly monitored, and ratings on the HRSD were performed every second week in the inpatients. All outpatients and discharged inpatients who continued to receive $\mathrm{T}_{4}$ were treated on an outpatient basis by one of the authors. During outpatient treatment the patients underwent regular checks on serum concentrations of thyroid hormones, ECG, and HRSD ratings at least once a month. Patients who continued to receive high-dose $T_{4}$ as outpatients for more than 6 months underwent serum hormone measurements and ECG recordings every 3 months and computer tomographic measurements of bone density (osteodensitometry) once a year.

For the patients taking $\mathrm{T}_{4}$ who were followed up, "remission," "recovery," and "relapse" were defined according to criteria recently suggested (Thase and Rush 1995; Thase et al. 1995; Frank et al. 1991). Remission was defined as attainment of a virtually asymptomatic status, equivalent to HRSD score of $\leqslant 7$ for at least 2 weeks. Recovery was defined as remission for $\geqslant 6$ consecutive months. Relapse was defined as a return of symptoms meeting the full criteria for an episode of major depression during the period of remission, whereas recurrence referred to the occurrence of a new episode of major depression during recovery.

The determinations of thyroid hormones $\left(\mathrm{T}_{4}, \mathrm{fT}_{4}, \mathrm{~T}_{3}\right)$ and TSH were performed by an endocrine research laboratory, all in duplicate with the following commercially available kits: the IRMA kit for TSH, RIA kits for $\mathrm{T}_{4}$ and $\mathrm{T}_{3}$ and the Dyno-Test for $\mathrm{fT}_{4}$, all from Henning, Berlin. Details on the sensitivities of the kits used and the interassay coefficients of variation determined by our laboratory have been published previously (Baumgartner et al. 1988, 1990). Normal ranges for serum concentrations of thyroid hormones and TSH had been determined previously by the same methods in 60 ageand sex-matched healthy subjects. The resulting ranges were as follows: total thyroxine $\left(\mathrm{T}_{4}\right) 45-125 \mu \mathrm{g} / \mathrm{L}$, free thyroxine $\left(\mathrm{fT}_{4}\right) 7-19 \mathrm{ng} / \mathrm{L}$, triiodothyronine $\left(\mathrm{T}_{3}\right)$ 0.8-1.6 $\mu \mathrm{g} / \mathrm{L}$ and TSH 0.4-3.5 mU/L.

\section{RESULTS}

The 17 patients who entered and completed the study had had a mean of $15.9 \pm 17.0$ (1-70) episodes of mood disorder. The mean length of the episode before $\mathrm{T}_{4}$ treatment was $11.5 \pm 13.8(2-50)$ months (see Table 1 ). Their mean HRSD score before $\mathrm{T}_{4}$ treatment was $26.6 \pm$ 4.7 (range: 20-37). On day 56, the mean HRSD rating had fallen to $11.6 \pm 6.8$ (range: $1-22$ ).

According to our criteria, eight patients fully remit- 


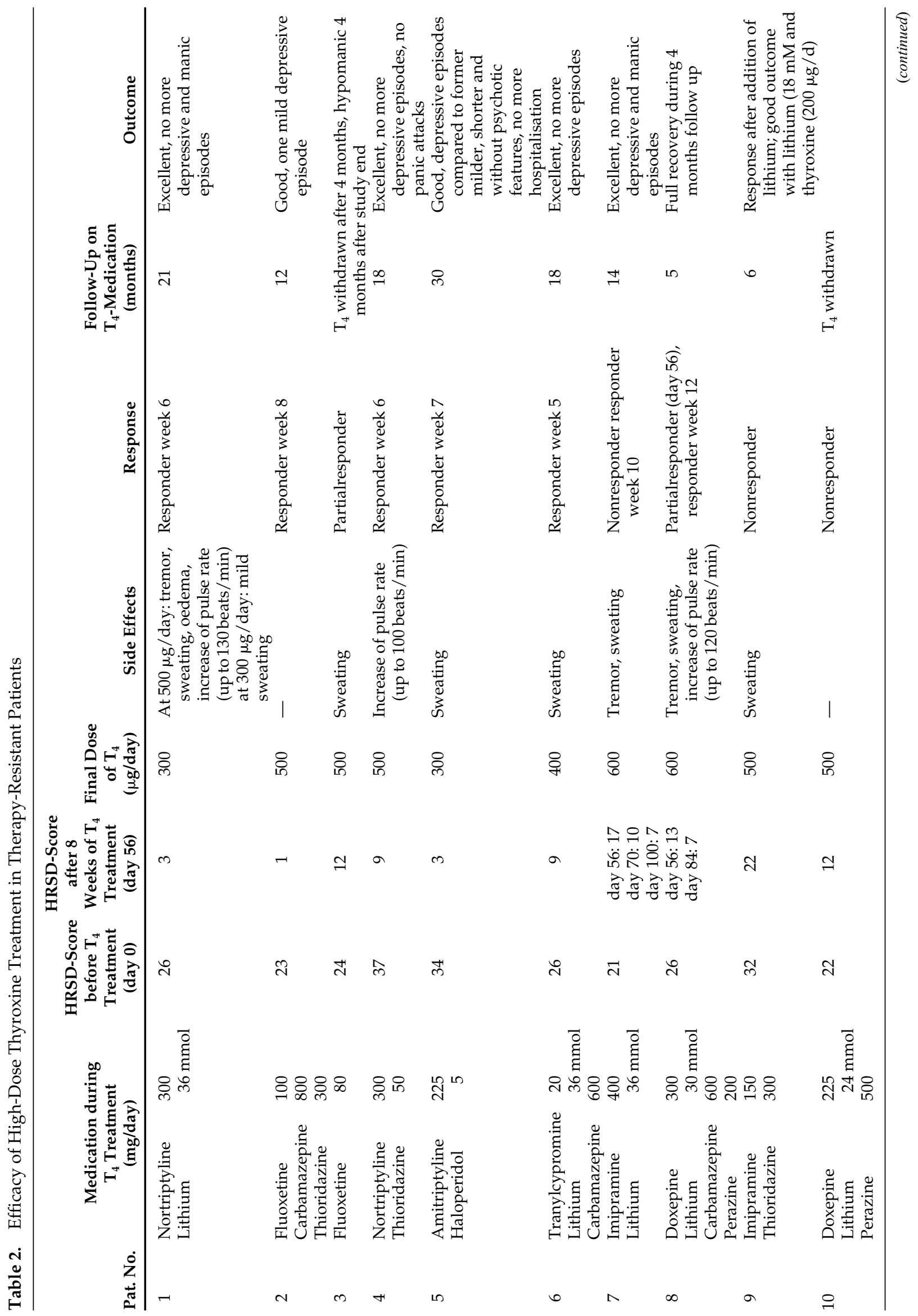




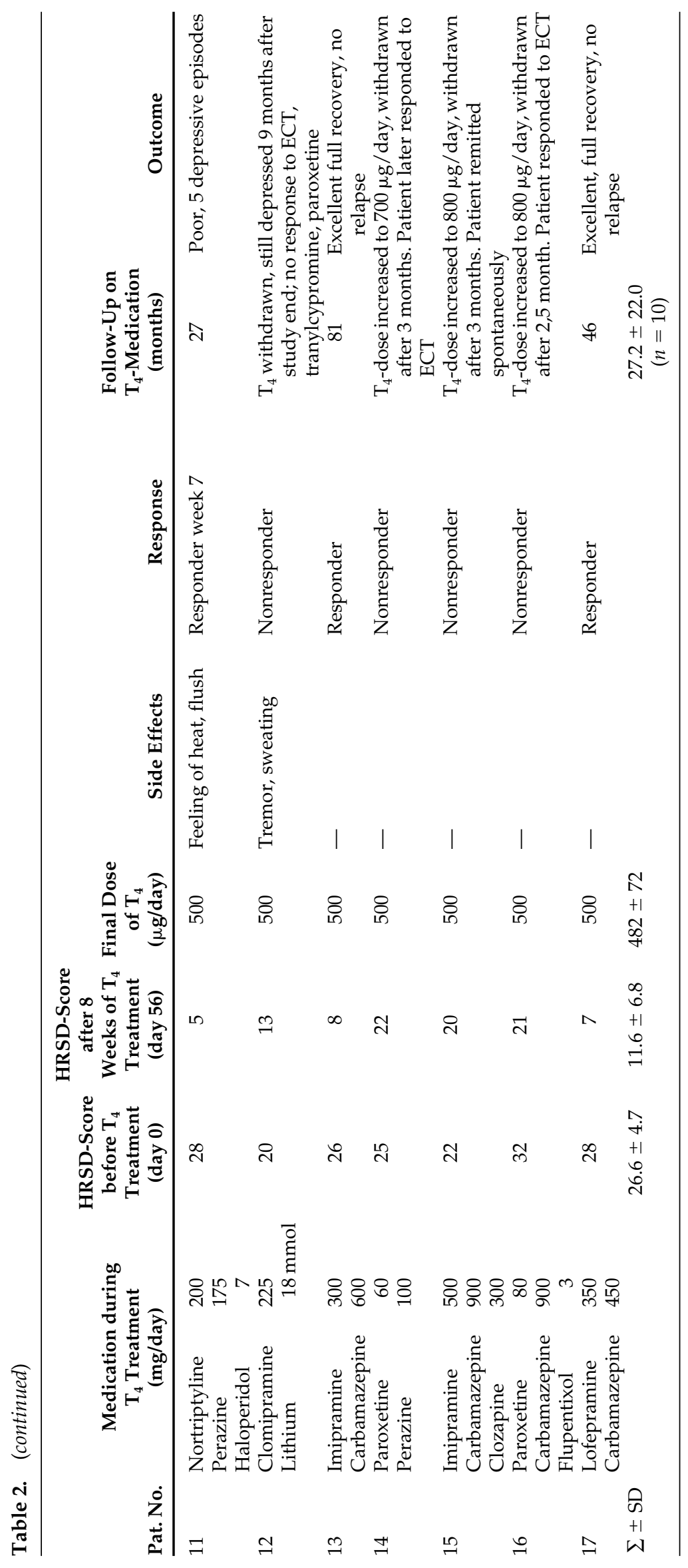


ted, two partially remitted, and seven did not remit (Table 2). In the remitted patients, the onset of remission did not occur before the period between weeks 5 and 8 . In all eight remitted patients, conventional prophylactic medication such as lithium and/or carbamazepine had previously proved to be ineffective in preventing further episodes. All of the patients therefore agreed that high-dose $\mathrm{T}_{4}$ treatment should be maintained as a trial of its prophylactic efficacy. At the time of writing, all eight remitted patients are still receiving high-dose $\mathrm{T}_{4}$, thus their mean total treatment period to date is $27.2 \pm$ 22.0 months (range: 5-81 months). Five of the patients recovered fully, i.e., they had no further depressive episodes. Two further patients (nos. 2 and 5, Table 2) had a positive outcome in the sense that their episodes of depression were much milder and shorter than previously and no longer require hospitalization. The 8th remitted patient (no. 11) had a poor outcome, experiencing five more depressive episodes during the 27-month followup period, necessitating hospitalization three times. The two partially remitted continued to take $\mathrm{T}_{4}$ beyond day 56, in the hope that full remission could be achieved. One of these patients (no. 3) had a hypomanic episode 4 months later, during which she discontinued $\mathrm{T}_{4}$ medication. Patient no. 8 responded fully on day 84 and recovered without any further recurrence.

In five of the seven nonremitted patients, no clear side effects had been observed up to day 56 . The dosage of $\mathrm{T}_{4}$ was therefore gradually increased to between 600 and $1,000 \mu \mathrm{g} /$ day. Four of these patients had side effects, mainly dyspnea on exercise, restlessness, and tachycardia, but no favorable effect on the depressive symptomatology. $\mathrm{T}_{4}$ was therefore withdrawn in these cases. The 5th patient (no. 7) responded to a combination of $600 \mu \mathrm{g} \mathrm{T}_{4}$ and $400 \mathrm{mg}$ imipramine on day 100 . He continued with this medication, fully recovered, and had no recurrence during the 14-month follow-up period.

In conclusion, nine of the patients in this study had an excellent $(n=7)$ or good $(n=2)$ long-term outcome on $\mathrm{T}_{4}$, whereas eight failed to benefit from high-dose $\mathrm{T}_{4}$ treatment. The $\mathrm{T}_{4}$ treatment did not provoke a manic episode in any patient. Of the five unipolar patients, three (nos. 4, 11, and 17) responded favorably to $\mathrm{T}_{4}$, whereas the other two did not (no. 15) or only partially (no. 8). Of the 12 bipolar patients, five (nos. 1, 2, 5, 6, and 13) responded to $\mathrm{T}_{4}$, whereas seven did not (nos. 7 , $9,10,12,14,16$ ) or only partially (no. 3 ).

The side effects that occurred during the 8-week study period are listed in Table 2 . Seven patients had no side effects at all. The others noted mild side effects such as tremor, sweating, flushing, and a slight increase in heart rate. Reduction of the dosage of $\mathrm{T}_{4}$ became necessary in only one patient (no. 1) during the 8-week trial, namely from 500 to $300 \mu \mathrm{g} /$ day, owing to an increase in heart rate of up to $130 \mathrm{BPM}$. Later, this patient remained well on $300 \mu \mathrm{g} \mathrm{T}_{4}$ /day throughout the 21-month follow-up period. The mean heart rate of all patients before $\mathrm{T}_{4}$ treatment (day 0) was $81.3 \pm 16.9$ BPM (range: $57-108$ BPM). On day 56 the mean heart rate had risen to $91.4 \pm 11.4$ BPM (range 81-120 BPM). The mean systolic blood pressure prior to $\mathrm{T}_{4}$ treatment was $118 \pm 11 \mathrm{~mm} \mathrm{Hg}$ and the mean diastolic pressure $77 \pm 7 \mathrm{~mm} \mathrm{Hg}$. This value was virtually unchanged on day $56(113 \pm 11 \mathrm{~mm} \mathrm{Hg}$ systolic pressure and $70 \pm 7 \mathrm{~mm} \mathrm{Hg}$ diastolic pressure).

The mean weight of all patients before the institution of $\mathrm{T}_{4}$ treatment was $72.7 \pm 17.9 \mathrm{~kg}$ (range: $49-107 \mathrm{~kg}$ ). On day 56 the mean weight was $72.3 \pm 19 \mathrm{~kg}$ (range: 49-109 kg). No "undesired" weight loss occurred in any patient. However, two young women, one of whom was receiving lithium and the other carbamazepine and both of whom had been chronically and greatly overweight before $\mathrm{T}_{4}$ treatment, did reach their ideal weight during the follow-up period without further difficulty. As already noted above, an increase in the $\mathrm{T}_{4}$ dosage above $700 \mu \mathrm{g} /$ day in four nonremitted patients led to dyspnea, restlessness, and tachycardia in all cases.

In the seven patients who continued to take $\mathrm{T}_{4}$ and were followed up for more than 1 year, osteodensitometry and ECGs were done at least twice: once when the decision was made to continue with the $\mathrm{T}_{4}$ treatment as prophylaxis and again 1 year later. Although this number is still too small for reliable statistical analysis, our preliminary evaluation of the results shows clearly that neither bone density nor heart size or function showed above average deterioration. No serious illnesses such as cardiac infarction or autoimmune disease occurred during follow-up in any of the patients receiving $\mathrm{T}_{4}$.

Serum concentrations of thyroid hormones and TSH before and after treatment with thyroxine are shown in Table 3. Before the start of $\mathrm{T}_{4}$ treatment only one patient (no. 7) had a slightly elevated baseline concentration of TSH (5.5 mU/L, Table 3), indicating a possible subclinical hypothyroidism. Values for total $\mathrm{T}_{4}$, free $\mathrm{T}_{4}$, and total $\mathrm{T}_{3}$ in all patients were well within the normal range before $\mathrm{T}_{4}$ institution, showing that the patient sample was euthyroid, that is, as based on their laboratory values, at least. In 16 of the 17 patients the serum levels of $T_{4}$ had at least doubled by the end of week 8 . This also applied to the serum levels of $\mathrm{fT}_{4}$ of all 17 patients. Rises in the concentrations of $\mathrm{T}_{3}$ were generally lower, the values increasing by more than $100 \%$ in only seven patients. No significant differences were noted between the changes in any hormone in the remitted patients over the 8-week period and those in the nonremitted patients, calculated by the Mann-Whitney $U$ test. The mean $\mathrm{T}_{4}-\mathrm{T}_{3}$ ratios before and after $\mathrm{T}_{4}$ treatment were 72.4 and 93.8, respectively $(p<.05$, Wilcoxon's rank test). In remitted patients $(n=8)$ the mean $\mathrm{T}_{4}-\mathrm{T}_{3}$ ratio increased from 70.5 to $99.8(p<.05)$, and in the nonremitted group $(n=7)$ from 70.1 to $89.7(p<.05)$ after $\mathrm{T}_{4}$ treatment. The differences between remitted and nonremitted patients were not statistically significant. 


\section{DISCUSSION}

The patient sample included in this study comprised the most therapy-resistant patients seen at our psychiatric clinic during a 5-year period. It therefore seems remarkable that about $50 \%$ of them remitted to high-dose $\mathrm{T}_{4}$ augmentation. It may be argued that our study was not double-blind, and we were therefore unable to control the rate of placebo response or spontaneous remission. However, a $50 \%$ placebo response seems rather unlikely in patients who had already been unsuccessfully treated with many different antidepressants, as well as combinations of antidepressants and lithium and/or neuroleptics. In their recent review, Thase and Rush (1995) and Thase et al. (1995) estimated the placebo response rate in therapy resistant depressed patients at between 0 and $10 \%$. Several double-blind studies in which different "augmentation strategies" such as the addition of $\mathrm{T}_{3}$ or lithium were tried with depressed patients who had failed to respond to a single antidepressant trial showed placebo response rates of between 19 and 25\% (Thase et al. 1989a,b). Placebo remission rates in chronically depressed patients seem to be even lower, e.g., $12 \%$ as shown in the study by Kocsis et al. (1988).

All of the patients who had a favorable outcome to $T_{4}$ treatment had suffered from at least one episode in the year preceding the institution of $\mathrm{T}_{4}$ augmentation. If the recovery seen in these patients had reflected a mere placebo response then relapses should have been expected with a high probability in a mean follow-up period of $27.2 \pm 22.0$ (5-81) months. Sackeim et al. (1990), for example, reported a relapse rate of $50 \%$ within 12 months after ECT treatment, the relapse rate being even higher in patients who had not responded adequately to antidepressant pharmacotherapy before ECT. The fact that all but one of the patients in whom $\mathrm{T}_{4}$ had an antidepressant effect remained stable during follow-up therefore also militates against a placebo effect of $\mathrm{T}_{4}$.

One might raise the question as to whether it is necessary to administer $T_{4}$ in supraphysiological doses or whether somewhat lower doses than those taken by our patients would have led to the same beneficial results. Especially in the first patients given high-dose $\mathrm{T}_{4}$ (Baumgartner et al. 1994a) for prophylaxis and also in the follow-up periods of the patients who responded to $\mathrm{T}_{4}$ augmentation we repeatedly noted that some mild depressive symptoms only subsided when $\mathrm{T}_{4}$ was further increased, e.g., from 500 to $600 \mu \mathrm{g} /$ day, and that after a reduction of only $100 \mu \mathrm{g} /$ day mild depressive symptoms are often reported 1 or 2 weeks later. Our impression that only supraphysiological doses are of value is also shared by other groups (Stancer and Persad 1982; Leibow 1983; Bauer and Whybrow 1986, 1990; Hurowitz and Liebowitz 1993) and is consistent with the negative results published by Joffe and Singer

Table 3. Serum Levels of Thyroid Hormones ${ }^{a}$ and Basal $\mathrm{TSH}^{a}$ before and after 8 Weeks of High-Dose Thyroxine Treatment

\begin{tabular}{|c|c|c|c|c|c|c|c|c|c|}
\hline \multirow{2}{*}{\multicolumn{5}{|c|}{ Before $\mathrm{T}_{4}$ Treatment }} & \multicolumn{5}{|c|}{ High-Dose $T_{4}$ Treatment } \\
\hline & & & & & & & & & \\
\hline Pat. No. & $\begin{array}{c}T_{4} \\
(\mu \mathrm{g} / \mathrm{L})\end{array}$ & $\begin{array}{c}\mathrm{fT}_{4} \\
(\mathrm{ng} / \mathrm{L})\end{array}$ & $\begin{array}{c}T_{3} \\
(\mu \mathrm{g} / \mathrm{L})\end{array}$ & $\begin{array}{c}\text { Basal TSH } \\
(\mathrm{mU} / \mathrm{L})\end{array}$ & $\begin{array}{c}\mathrm{T}_{4} \\
(\mu \mathrm{g} / \mathrm{L})\end{array}$ & $\begin{array}{c}\mathrm{fT}_{4} \\
(\mathrm{ng} / \mathrm{L})\end{array}$ & $\begin{array}{c}\mathrm{T}_{3} \\
(\mu \mathrm{g} / \mathrm{L})\end{array}$ & $\begin{array}{c}\text { Basal TSH } \\
(\mathrm{mU} / \mathrm{L})\end{array}$ & $\begin{array}{c}\text { Dose } \\
\text { ( } \mu \mathrm{g} / \text { day })\end{array}$ \\
\hline 1 & 89 & 8.8 & 1.8 & 0.5 & 153 & 28.1 & 2.2 & 0.01 & 300 \\
\hline 2 & 59 & 4.9 & 1.7 & 0.8 & 129 & 29.6 & 1.6 & 0.04 & 500 \\
\hline 3 & 126 & 14.3 & 1.2 & 1.2 & 172 & 44.0 & 2.1 & 0.01 & 500 \\
\hline 4 & 80 & 13.5 & 1.2 & 2.5 & 188 & 38.7 & 2.7 & 0.01 & 500 \\
\hline 5 & 102 & 10.7 & 0.9 & 0.3 & 198 & 27.5 & 1.0 & 0.2 & 300 \\
\hline $6^{b}$ & 61 & 9.8 & 0.6 & 0.4 & 127 & 21.8 & 1.0 & 0.01 & 500 \\
\hline 7 & 68 & 9.2 & 1.0 & 5.5 & 128 & 18.9 & 1.8 & 0.01 & 500 \\
\hline $8^{b}$ & 86 & 8.5 & 1.2 & 3.5 & 121 & 19.4 & 1.4 & 0.03 & 600 \\
\hline 9 & 52 & 6.8 & 0.8 & 0.6 & 166 & 66.6 & 1.9 & 0.01 & 500 \\
\hline 10 & 62 & 7.7 & 0.9 & 2.7 & 113 & 12.4 & 1.7 & 0.02 & 500 \\
\hline 11 & 77 & 5.9 & 1.2 & 2.8 & 175 & 19.5 & 2.6 & 0.01 & 500 \\
\hline 12 & 66 & 5.3 & 1.2 & 1.7 & 187 & 23.0 & 1.8 & 0.9 & 500 \\
\hline $13^{b}$ & 55 & 8.4 & 1.0 & 1.9 & 138 & 22.4 & 1.6 & 0.01 & 500 \\
\hline $14^{b}$ & 86 & 12.3 & 0.8 & 1.5 & 217 & 29.3 & 1.9 & 0.03 & 500 \\
\hline 15 & 75 & 10.4 & 1.0 & 2.0 & 180 & 18.5 & 1.9 & 0.01 & 500 \\
\hline 16 & 57 & 9.3 & 1.1 & 1.5 & 136 & 25.5 & 1.5 & 0.02 & 500 \\
\hline 17 & 48 & 7.5 & 0.6 & 1.3 & 141 & 22.0 & 1.4 & 0.01 & 500 \\
\hline$\Sigma \pm S D$ & $73.5 \pm 20.1$ & $9.02 \pm 2.67$ & $1.07 \pm 0.32$ & $1.81 \pm 1.32$ & $157.0^{c} \pm 30.8$ & $27.5^{c} \pm 12.6$ & $1.77^{c} \pm 0.46$ & $0.07^{c} \pm 0.21$ & $482^{c} \pm 72.8$ \\
\hline
\end{tabular}

${ }^{a}$ For normal ranges see methods.

${ }^{b}$ Patients were already receiving physiological doses of thyroxine.

${ }^{c} p<.01$ compared with the values before $\mathrm{T}_{4}$ treatment.

$\mathrm{T}_{4}=$ total thyroxine; $\mathrm{fT}_{4}=$ free thyroxine; $\mathrm{T}_{3}=$ triiodothyronine; $\mathrm{TSH}=$ thyroid-stimulating hormone (thyrotropine). 
(1990), according to which augmentation with $150 \mu \mathrm{g} \mathrm{T}$ remained ineffective in treatment-resistant depressed patients. Finally, the fact that four of our patients had already been receiving substitution therapy with physiological doses of $\mathrm{T}_{4}$ and were still treatment-resistant also supports the above conclusion.

Our experience in treating our first patients with high-dose $\mathrm{T}_{4}$ (Baumgartner et al. 1994a) as well as that reported by others (Bauer and Whybrow 1986; Hurowitz and Liebowitz 1993) suggests that $T_{4}$ may have a prophylactic and also an antidepressant effect only when given together with a standard antidepressant or prophylactic medication. The patients in the present study repeatedly reported the recurrence of mild depressive symptoms after attempts to slightly reduce their doses of antidepressant medication (which in some cases were extremely high), particularly during the follow-up period. In cases in which an increase the dosage of $\mathrm{T}_{4}$ was not advisable because the serum levels of thyroid hormones were already high and/or because of side effects, the dosage of the antidepressant was raised and the prodromal symptoms subsided in all cases.

It is surprising how few side effects were observed, during both the 8-week augmentation period and the subsequent follow-up period. However, this is in line with previous observations made in rapid-cycling bipolar patients during high-dose $\mathrm{T}_{4}$ treatment (Stancer and Persad 1982; Leibow 1983; Bauer and Whybrow 1986, 1990; Hurowitz and Liebowitz 1993). The results of our preliminary evaluation of the effects of long-term $\mathrm{T}_{4}$ treatment on bone density are also consistent with the results obtained by Whybrow's group (Whybrow 1994; Gyulai et al. 1997), i.e., no abnormal increase in osteoporosis parameters. As serum $\mathrm{T}_{4}$ and $\mathrm{fT}_{4}$ were clearly in the hyperthyroid range in all of our patients toward the end of the augmentation period and during the follow-up phase, the question arises as to why these patients did not suffer from symptoms of Graves' disease. We are currently investigating the question as to whether depressed patients are less sensitive to thyroid hormones than patients with hypothyroidism of autoimmunologic origin.

The biochemical mechanisms underlying the antidepressive and prophylactic effects of $\mathrm{T}_{4}$ are as yet unclear. It has been suggested that the beneficial effects of highdose $T_{4}$ prophylaxis seen in patients with rapid-cycling bipolar disorder may be due to a correction of subclinical hypothyroidism, which is frequently seen in these patients (Bauer and Whybrow 1990). However, only one patient in our study showed laboratory values indicative of subclinical hypothyroidism; all the others were clearly euthyroid before $\mathrm{T}_{4}$ augmentation was instituted. The effects of $\mathrm{T}_{4}$ are therefore obviously not attributable to a correction of manifest or subclinical hypothyroidism.

Serum levels of $\mathrm{T}_{4}$ are of paramount importance for the action of thyroid hormones in the brain insofar as hardly any of the physiologically active hormone $\mathrm{T}_{3}$ is taken up from the circulation, but derived from intracellular deiodination of $\mathrm{T}_{4}$ (Crantz et al. 1982). It therefore seems interesting that serum levels of $\mathrm{T}_{4}$ have been shown to fall during electroconvulsive therapy, treatment with various antidepressants such as imipramine, desipramine, clomipramine, and maprotiline, treatment with carbamazepine and after cognitive psychotherapy and treatment with bright and dim light (Kirkegaard and Faber 1981; Roy-Byrne et al. 1984; Baumgartner et al. 1988; Joffe and Singer 1990; Baumgartner et al. 1996; Joffe et al. 1996). In the majority of all studies published to date, these reductions in serum concentrations of $\mathrm{T}_{4}$ were significantly correlated to the degree of clinical response (Kirkegaard and Faber 1981; Roy-Byrne et al. 1984; Baumgartner et al. 1988; Joffe and Singer 1990; Baumgartner et al. 1996; Joffe et al. 1996). Furthermore, the importance of initially high serum levels of $T_{4}$ for the mechanisms of action of antidepressants is also underlined by the results of several studies that have shown that high serum concentrations of $\mathrm{T}_{4}$ predict a favorable response to such different antidepressant therapies such as antidepressant drugs (Prange et al. 1969; Baumgartner et al. 1988), total sleep deprivation (Baumgartner et al. 1990), and partial sleep deprivation (Szuba et al. 1992).

A series of animal experiments has shown that the declines in serum concentrations of $\mathrm{T}_{4}$ seen during antidepressant treatment are most likely due to enhanced degradation of $\mathrm{T}_{4}$ to $\mathrm{T}_{3}$, i.e., enhanced activity of the $5^{\prime} \mathrm{II}$ deiodinase isoenzyme in the CNS (Campos-Barros et al. 1994; Baumgartner et al. 1994b). As a result, the concentrations of $\mathrm{T}_{3}$ rise in various regions of the rat $\mathrm{CNS}$ after subchronic administration of different antidepressant drugs such as desipramine and fluoxetine, as well as after sleep deprivation (Campos-Barros and Baumgartner 1994; Campos-Barros et al. 1993, 1995). An increase in the activity of 5'II deiodinase and/or an inhibition of the activity of the 5D-III isoenzyme have now also been reported after 14 days' administration of lithium and carbamazepine (Baumgartner et al. 1997).

In conclusion, very different antidepressant and prophylactic treatments seem to affect thyroid hormone metabolism in the CNS by enhancing the degradation of $\mathrm{T}_{4}$ and increasing tissue concentrations of $\mathrm{T}_{3}$. In other words, some antidepressants, and also lithium and carbamazepine, may "need" $\mathrm{T}_{4}$ to unfold their specific actions. Therefore, the more $\mathrm{T}_{4}$ is available to the brain, the more effective antidepressant therapies may be. This hypothesis would also explain the fact that-at least according to the clinical impression gained by both Bauer and Whybrow (1990) and ourselves, highdose $T_{4}$ treatment is effective only when given together with a conventional antidepressant or prophylactic drug.

Studies investigating the as yet almost unknown 
functions of $\mathrm{T}_{3}$ in the adult CNS are needed for further clarification of the question as to whether an increase in $\mathrm{T}_{3}$ function may be involved in the as yet unknown mechanisms of action of antidepressant drugs.

Finally, why both hypo- and hyperthyroidism should induce symptoms of depression and other disorders is one of the unsolved riddles of thyroid disorders (Hall et al. 1986). In this connection it is, however, noteworthy that in our study approximately $50-60 \%$ of the patients responded to $\mathrm{T}_{4}$ augmentation, whereas the others failed to benefit at all. Moreover, the fact that some of the depressed patients also seemed to benefit from lowdose $\mathrm{T}_{3}$ treatment (for a review, see Joffe et al. 1995) which has exactly the opposite effect on thyroid hormone function in the CNS from $\mathrm{T}_{4}$ treatment-needs explaining. Although this remains speculative at present, it may be that patients who do not respond to $\mathrm{T}_{4}$ are already "functionally hyperthyroid" and may therefore profit from low-dose $\mathrm{T}_{3}$ treatment, in line with the hypothesis put forward by Joffe (Joffe et al. 1995). It would therefore be interesting to investigate whether patients who fail to respond to high-dose $T_{4}$ improve during low-dose $\mathrm{T}_{3}$ administration and vice versa.

\section{ACKNOWLEDGMENTS}

The authors thank Michael Linden, M.D., for valuable support in the preparation of the study. Preliminary results of this study were presented at the 3rd International Conference on Refractory Depression in Napa, California, October 18-21, 1995 and the 149th Annual Meeting of the American Psychiatric Association in New York, May 4-9, 1996.

\section{REFERENCES}

American Psychiatric Association (1987): Diagnostic and Statistical Manual of Mental Disorders, 3rd ed. rev. DSMIII-R. Washington, DC, American Psychiatric Association

Bauer MS, Whybrow PC (1986): The effect of changing thyroid function on cyclic affective illness in a human subject. Am J Psychiatry 143:633-636

Bauer MS, Whybrow PC (1990) Rapid cycling bipolar affective disorders. II. Treatment of refractory rapid cycling with high-dose levothyroxine: A preliminary study. Arch Gen Psychiatry 47:435-440

Baumgartner A, Gräf KJ, Kürten I, Meinhold H (1988): The hypothalamic pituitary thyroid axis in psychiatric patients and healthy subjects. Part II. Repeated measurements of thyroxine, free thyroxine, triiodothyronine, free triiodothyronine, and reverse triiodothyronine in patients with major depressive disorder and schizophrenia and healthy subjects. Psychiatry Res 24:283-305

Baumgartner A, Gräf KJ, Kürten I, Meinhold H, Scholz P (1990): Neuroendocrinological investigations during sleep deprivation in depression. Biol Psychiatry 28:556568
Baumgartner A, Bauer M, Hellweg R (1994a): Treatment of intractable nonrapid cycling bipolar affective disorder with high-dose thyroxine: An open clinical trial. Neuropsychopharmacology 10:183-189

Baumgartner A, Dubeyko M, Campos-Barros A, Eravci M, Meinhold H (1994b): Subchronic administration of fluoxetine to rats affects triiodothyronine production and deiodination in regions of the cortex and the limbic forebrain. Brain Res 635:68-74

Baumgartner A, Volz HP, Campos-Barros A, Stieglitz RD, Mansmann U, Mackert A (1996): Serum concentrations of thyroid hormones in patients with nonseasonal affective disorders during treatment with bright and dim light. Biol Psychiatry 40:899-907

Baumgartner A, Pinna G, Hiedra L, Gaio U, Hessenius C, Campos-Barros A, Eravci M, Prengel H, Thoma R, Meinhold H (1997) The effects of lithium and carbamazepine on thyroid hormone metabolism in rat brain. Neuropsychopharmacology 16:25-41

Campos-Barros A, Baumgartner A (1994): Effects of chronic desipramine treatment on thyroid hormone concentrations in rat brain: Dependency on drug dose and brain area. Biol Psychiatry 35:214-216

Campos-Barros A, Köhler R, Müller F, Eravci M, Meinhold H, Wesemann W, Baumgartner A (1993): The influence of sleep deprivation on thyroid hormone metabolism in rat frontal cortex. Neurosci Lett 162:145-148

Campos-Barros A, Meinhold H, Stula M. Müller F, Köhler R, Eravci M, Putzien O, Baumgartner A (1994): The influence of desipramine on thyroid hormone metabolism in rat brain. J Pharmacol Exp Ther 268:1143-1152

Campos-Barros A, Meinhold H, Köhler R, Müller F, Eravci M, Baumgartner A (1995): The effects of desipramine on thyroid hormone concentrations in rat brain. Naunyn Schmiedeberg Arch Pharmacol 351:469-474

Crantz FR, Silva JE, Larsen PR (1982): Analysis of the sources and quantity of 3,5,3'-iodothyronine specifically bound to nuclear receptors in rat cerebral cortex and cerebellum. Endocrinology 110:367-375

Frank E, Prien RF, Jarrett RB, Keller MB, Kupfer DJ, Lavori PW, Rush AJ, Weissmann MM (1991): Conceptualization and rationale for consensus definitions of terms in major depressive disorder. Arch Gen Psychiatry 48:851855

Garbutt JC, Mayo JP, Gillette GM, Little KY, Mason GA (1986): Lithium potentiation of tricyclic antidepressants following lack of $\mathrm{T}_{3}$ potentiation. Am J Psychiatry 143: 1038-1039

Gitlin MJ, Weiner H, Fairbanks L, Hershman JM, Friedfeld N (1987): Failure of $\mathrm{T}_{3}$ to potentiate tricyclic antidepressant response. J Affective Disord 13:267-272

Goodwin F, Prange AJ, Post RM, Muscettola G, Lipton MA (1982): Potentiation of antidepressant effects by L-triiodothyronine in tricyclic nonresponders. Am J Psychiatry 139:34-38

Gyulai L, Whybrow PC, Jaggi J, Bauer MS, Younkin S, Rubin L, Attie M (1997): Bone mineral density and L-thyroxine treatment in rapidly cycling bipolar disorder. Biol Psychiatry 41:503-506

Hall RCW, Stickney S, Beresford TP (1986): Endocrine disease and behavior. Integr Psychiatry 4:122-135 
Hamilton M (1960): A rating scale for depression. J Neurol Neurosurg Psychiatry 23:56-62

Howland RH (1993): Chronic depression. Hosp Commun Psychiatry 44:633-639

Hurowitz GI, Liebowitz MR (1993): Antidepressant-induced rapid cycling: Six case reports. J Clin Psychopharmacol 13:52-56

Joffe RT, Roy-Byrne PP, Udhe TW, Post RM (1984): Thyroid function and affective illness: A reappraisal. Biol Psychiatry 19:1685-1691

Joffe RT, Segal Z, Singer W (1996): Change in thyroid hormone levels following response to cognitive therapy for major depression. Am J Psychiatry 153:411-413

Joffe RT, Singer W, Levitt AJ, MacDonald C (1993): A placebocontrolled comparison of lithium and triiodothyronine augmentation of tricyclic antidepressants in unipolar refractory depression. Arch Gen Psychiatry 50:387-393

Joffe RT, Singer W (1990): A comparison of triiodothyronine and thyroxine in the potentiation of tricyclic antidepressants. Psychiatry Res 32:241-251

Joffe RT, Sokolov STH, Singer W (1995): Thyroid hormone treatment of depression. Thyroid 5:235-239

Keller MB, Lavori PW, Mueller TI, Endicott J, Coryell W, Hirschfeld RMA, Shea T (1992): Time to recovery, chronicity, and levels of psychopathology in major depression. Arch Gen Psychiatry 49:809-816

Kirkegaard C, Faber J (1981): Altered serum levels of thyroxine, triiodthyronines and diiodothyronines in endogenous depression. Acta Endocrinol 96:199-207

Kocsis JH, Frances AJ, Voss C, Mann JJ, Mason BJ, Sweeney J (1988): Imipramine treatment for chronic depression. Arch Gen Psychiatry 45:253-257

Lee AS, Murray RM (1988): The long-term outcome of Maudsley depressives. Br J Psychiatry 153:741-751

Leibow D (1983): L-thyroxine for rapid-cycling bipolar illness. Am J Psychiatry 140:1255-1256

Nierenberg AA, Amsterdam JD (1990): Treatment-resistant depression: Definition and treatment approaches. J Clin Psychiatry 51:39-47
Picinelli M, Wilkinson G (1994): Outcome of depression in psychiatric settings. Br J Psychiatry 164:297-304

Prange AJ, Wilson IC, Rabon AM, Lipton MA (1969): Enhancement of imipramine antidepressant activity by thyroid hormone. Am J Psychiatry 126:457-469

Roy-Byrne PP, Joffe RT, Uhde TW, Post RM (1984): Carbamazepine and thyroid function in affectively ill patients. Arch Gen Psychiatry 41:1150-1153

Sackeim HA, Prudic J, Devanand DP, Decina P, Kerr B, Malitz $S$ (1990): The impact of medication resistance and continuation pharmacotherapy on relapse following response to electroconvulsive therapy in major depression. J Clin Psychopharmacol 10:96-104

Scott J (1988): Chronic depression. Br J Psychiatry 153:287297

Stancer HC, Persad E (1982): Treatment of intractable rapidcycling manic-depressive disorder with levothyroxine. Arch Gen Psychiatry 39:311-312

Szuba MP, Altshuler LL, Baxter LR (1992): Thyroid function and partial sleep deprivation response. Arch Gen Psychiatry 49:581-582

Thase ME, Kupfer DJ, Jarrett DB (1989a): Treatment of imipramine-resistant recurrent depression. I. An open clinical trial of adjunctive L-triiodothyronine. J Clin Psychiatry 50:385-388

Thase ME, Kupfer DJ, Frank E, Jarrett DB (1989b): Treatment of imipramine-resistant recurrent depression. II. An open clinical trial of lithium augmentation. J Clin Psychiatry 50:413-417

Thase ME, Rush AJ (1995): Treatment-resistant depression. In Bloom FE, Kupfer DJ (eds), Psychopharmacology. The Fourth Generation of Progress. New York, Raven, pp 1081-1097

Thase ME, Rush AJ, Kasper S, Memeroff CB (1995): Tricyclics and newer antidepressant medications: Treatment options for treatment-resistant depressions. Depression 2:152-168

Whybrow PC (1994): The therapeutic use of triiodothyronine and high dose thyroxine in psychiatric disorder. Acta Medica Austriaca 21:47-52 